\title{
Grażyna Habrajska*
}

\section{Interpretacja tekstów w różnych dyskursach}

Pojęcie dyskursu w ostatnich latach doczekało się wielu definicji zarówno lingwistycznych, jak i socjologicznych. Nie będę ich tu przytaczać, bowiem nie odpowiadają one naszemu ujęciu komunikacyjnemu. Nie jest zatem dla nas dyskurs ani językiem, ani dyskusją naukową, ani tekstem, ani zbiorem tekstów. Naszym zdaniem jest to obszar sensów, powstałych wskutek interpretacji tekstów, które to sensy pozostają $\mathrm{w}$ naszej pamięci i są aktywowane $\mathrm{w}$ miarę potrzeb komunikacyjnych. Tekst, którego nie możemy zinterpretować, nie jest dla nas tekstem. Interpretacja jest procesem umożliwiającym powstanie tekstu, który sam w sobie nie jest znaczący, ale po interpretacji takim być musi. Kiedy zauważamy jakikolwiek tekst, jeszcze nie wiedząc, że to jest tekst, hipotetycznie zakładamy, że nim jest, ale dopiero jego interpretacja, która prowadzi do zrozumienia, czyli odkrycia przekazanego sensu, powoduje, że tekstem się staje. Jeśli po zauważeniu tekstu nie mamy gotowości do jego interpretacji, to dla nas przestaje on być tekstem. Sensy uzyskane w wyniku interpretacji i zrozumienia tekstu współtworzą dyskurs, w obrębie którego powstał zinterpretowany tekst.

Teksty, których sensy tworzą poszczególne dyskursy, mogą mieć formę werbalną albo niewerbalną (wizualną, muzyczną itd.). Innymi słowy, forma werbalna, wizualna, dźwiękowa itd. to forma tekstu, a nie dyskursu, bowiem sensy nie mają formy. Zapamiętane i przechowywane w naszej pamięci sensy umożliwiają nam rozumienie i interpretowanie nowych tekstów, pojawiających się w przestrzeni danego dyskursu. Z kolei po zinterpretowaniu tych nowych tekstów zapamiętane ich sensy poszerzą obszar sensów dyskursu, w którym powstały. Sensy tworzące dany dyskurs stanowią swoistą bazę odniesienia - własną logikę - pozwalającą na interpretację przekazu.

* Prof. dr hab., Uniwersytet Łódzki, Wydział Filologiczny, Katedra Dziennikarstwa i Komunikacji Społecznej, e-mail: grazyna.habrajska@uni.lodz.pl

1 A. Awdiejew, Logiki dyskursów [w druku]. 
Typologie dyskursów zawsze wiązały się z przyjętą ich definicją. W ujęciu komunikatywistycznym zakładamy, że

[...] różne rodzaje komunikacji mają różne bazy odniesienia sensu i różne mechanizmy interpretacyjne, które pozwalają na osiągniecie stanu rozumienia [...]. Inaczej mówiąc, można przyjąć, że istnieje jedna początkowa uniwersalna logika, pozwalająca na racjonalizację całego procesu analizy rzeczywistości przez człowieka, jej kategoryzacji i ustalenia związków przyczynowo-skutkowych, lecz nie pozwala ona na skuteczną interpretację i rozumienie przekazów we wszystkich złożonych sytuacjach komunikacyjnych i w każdym wyspecjalizowanym dyskursie².

Z tego wynika prosty wniosek, że musimy się nauczyć, jak uczestniczyć w poszczególnych dyskursach. Uwzględniając ogólny cel komunikacyjny i swoistą bazę odniesienia sensu, wyróżniliśmy dyskursy: potoczny, naukowy, urzędowy, publicystyczny i artystyczny ${ }^{3}$, w obrębie których można wyróżniać tematycznie węższe subdyskursy.

Pierwotna forma komunikacji powstała w obrębie dyskursu potocznego, w celu umożliwienia ludziom koordynacji wspólnych działań i wyrażania postaw emocjonalnych ${ }^{4}$. Naszym zdaniem, ten dyskurs stanowi podstawę wszystkich pozostałych $^{5}$. Bardzo przejrzyście pisze o tym Aleksy Awdiejew:

Dyskurs potoczny, będąc prototypem wszystkich późniejszych wyspecjalizowanych dyskursów, ma charakter syntetyczny - cały obszar produkowanego sensu dzieli się na kilka powiązanych ze sobą modułów: ideacyjny - tworzący ontologiczny opis wspólnie obserwowanej rzeczywistości, którego celem komunikacyjnym jest prawdziwe (a raczej prawdopodobne) przedstawienie tej rzeczywistości, w tekście ten model reprezentują wypowiedzi asertywne i modalne; aksjologiczny - tworzący ocenę wspólnie obserwowanej rzeczywistości, którego celem komunikacyjnym jest wartościowanie, a w tekście reprezentują go wypowiedzi oceniające (opinie); dyrektywny - wyrażający wolę uczestników komunikacji do zmiany obserwowanej rzeczywistości, co w tekście reprezentują akty żądania, prośby, proponowania, życzenia itd. oraz ludyczny, którego celem komunikacyjnym jest przeżycie estetyczne i który $\mathrm{w}$ tekście jest reprezentowany przez rozmaite gry językowe, narracje non-bona-fide

2 Tamże.

3 A. Awdiejew, G. Habrajska, Wprowadzenie do gramatyki komunikacyjnej, t. 2, Wydawnictwo Leksem, Łask 2006, s. 190-193.

4 Zob. B. Malinowski, Ogrody koralowe i ich magia, w: tenże, Dzieła, t. 5, PWN, Warszawa 1987.

5 Szczegółowy opis dyskursu naukowego przedstawiliśmy w cytowanej książce Wprowadzenie do gramatyki komunikacyjnej, a jego poziom interakcyjny szczegółowo opisał Aleksy Awdiejew, Gramatyka interakcji werbalnej, Wydawnictwo Uniwersytetu Jagiellońskiego, Kraków 2004. 
i inne realizacje wyobrażeniowe. Wszystkie te wzajemnie powiązane moduły wprowadzają specyficzne odcienie sensu i tworzą syntetyczny obraz rozumienia [...]. Przedstawione moduły dyskursu potocznego, jako dyskursu pierwotnego, stanowią, naszym zdaniem, zalążki wszystkich znanych nam dyskursów, które pojawiły się w historycznym rozwoju komunikacji międzyludzkiej ${ }^{6}$.

Przykładami wypowiedzi występujących w module ideacyjnym są asercje, np. Janek przyjechał wczoraj, kiedy wypowiadający ten komunikat bierze odpowiedzialność za jego prawdziwość i weryfikowalność, oraz wypowiedzi modalne, np. Janek na pewno wczoraj przyjechat (pewność), Janek chyba wczoraj przyjechat (przypuszczenie), Wątpię, żeby Janek wczoraj przyjechał (wątpliwość) itd. Moduł aksjologiczny reprezentują akty emotywno-oceniające, np. Jesteś wspaniałym partnerem, Ciesze się, że cię poznatem, Jest pan chamem itd. Wypowiedzi formułowanie w module dyrektywnym w czystej postaci wpływają na odbiorcę, czyli w większości mają charakter perswazyjny. Należą tu takie akty mowy, jak prośba: Czy mógłbyś sprawdzić mój tekst?, polecenie: Wynieś śmieci!, zakaz: Palenie zabronione! Z kolei moduł ludyczny reprezentowany jest przez takie wypowiedzi jak: Jurek ogórek kiełbasa i sznurek, dzieńdoberek, mam takq obamę! itd. We wszystkich przypadkach mówiący porzucają poziom merytoryczny i włączają poziom non-bona-fide.

$\mathrm{Z}$ modułu ideacyjnego $\mathrm{w}$ dyskursie potocznym wywodzi się dyskurs naukowy, który powstaje z nałożenia na ten moduł dyscypliny logicznej. W dyskursie naukowym celem komunikacyjnym jest dążenie do wykrycia prawdy/wiarygodności. Nadawca tworzący teksty w obrębie tego dyskursu dąży do znalezienia sposobów wiarygodnego opisu rzeczywistości, metodologii jej badania, sformułowania ogólnych reguł, przewidujących zmiany jakościowe i ilościowe w opisywanych obiektach badawczych. Z tego punktu widzenia najważniejszą funkcją tych tekstów jest logiczna funkcja prawdziwości, a ich struktura jest podporządkowana odpowiednio zorganizowanym ciągom argumentacyjnym. Argumentacja w dyskursie naukowym ma charakter merytoryczny $(1-2), \mathrm{np}$.:

(1) $\left(\mathrm{P}_{\mathrm{OG}}\right)^{7}$ : wszyscy ludzie są śmiertelni

$\left(\mathrm{P}_{\mathrm{SZ}}\right)$ : Sokrates jest człowiekiem

(K): Sokrates jest śmiertelny

(2) $\left(\mathrm{P}_{\mathrm{OG}}\right)$ : gotujaca się woda intensywnie paruje i bulgocze

$\left(\mathrm{P}_{\mathrm{SZ}}\right)$ : woda $w$ czajniku intensywnie paruje

$\left(\mathrm{P}_{\mathrm{SZ}_{2}}\right)$ : woda w czajniku bulgocze

(K): woda w czajniku się gotuje

6 A. Awdiejew, Logiki dyskursów.

$7 \quad\left(P_{\text {oG }}\right)$ - przesłanka ogólna; $\left(P_{S Z}\right)$ - przesłanka szczegółowa; $(K)$ - konkluzja 
Interpretacja tekstów naukowych wymaga od ich odbiorcy specjalistycznego przygotowania. Pole interpretacji związane jest tu z posiadaniem wiedzy w danej dziedzinie nauki. Dlatego właściwy odbiór tekstu naukowego wymaga głębokiego przygotowania merytorycznego i wcześniejszego doświadczenia w odbiorze podobnych tekstów. Inaczej mówiąc, aby rozumieć wykład naukowy odbiorca powinien mieć stały kontakt z praktyką i teorią danej dziedziny wiedzy, czyli na co dzień korzystać z dyskursu naukowego. Przykładami mogą być następujące teksty - pierwszy z subdyskursu matematycznego (3), a drugi z subdyskursu przyrodniczego (4):

(3) Wielkość $y$ jest funkcja (zmienna zależna) wielkości $x$ (zmiennej niezależnej lub argumentu), gdy wielkości te są związane jakąś zależnością („zależnością funkcjonalną"); nadając wielkości $x$ różne wartości, otrzymujemy na mocy tej zależności odpowiednie wartości $y$.

Oznaczamy to tak: $y=f(x)$, albo $y=\varphi(x)$, albo $y=F(x)$ itd.

Znak $f$ (albo $\varphi, F$ ) oznacza pewien zespół działań, które muszą być wykonane względem każdej poszczególnej wartości $x$, dla otrzymania odpowiedniej wartości $y$.

Np. $y=2 x^{2}+3, y=x+\sin x$.

(4) W otaczającej nas przyrodzie rośliny i zwierzęta występują w niezliczonej liczbie różnorodnych indywiduów. Osobniki o jednakowym wyglądzie zewnętrznym i budowie wewnętrznej, które mają zdolność wydawania potomstwa, łączymy w jeden gatunek.

Z tego punktu widzenia przygotowania naukowe obejmują nie tylko przyswojenie sobie niezbędnych informacji naukowych, ale również umiejętność komunikowania się językowego w kręgu specjalistów. Teksty naukowe są realizowane przede wszystkim w postaci graficznej jako artykuły, monografie, podręczniki, recenzje naukowe itp. Istnieją również w postaci ustnej jako wystąpienia na konferencjach i sympozjach naukowych, w dyskusjach i wykładach poświęconych danej dziedzinie wiedzy ${ }^{8}$.

Rozwinięcie modułu dyrektywnego $\mathrm{w}$ czystej postaci stanowi dyskurs prawny, którego odmianą, z jaką stykamy się wszyscy, jest subdyskurs urzędowy. Każdy dokument prawny czy urzędowy, będąc składnikiem całego korpusu tekstów prawnych, powstających $\mathrm{w}$ obrębie dyskursu prawnego, powinien spełniać podstawowy warunek zgodności z innymi tekstami tego typu, mającymi charakter

8 Szczegółowy opis dyskursu naukowego przedstawiliśmy w cytowanej książce Wprowadzenie do gramatyki komunikacyjnej. 
nadrzędny lub podrzędny w stosunku do danego tekstu. Co oznacza, że prawa i obowiązki wszystkich osób prawnych, przedstawione w konkretnym dokumencie, muszą się zgadzać z prawami i obowiązkami przedstawionymi w pozostałych dokumentach. W tym dyskursie nadawca i odbiorca występują $\mathrm{w}$ roli ściśle określonych jednostek prawnych, posiadających z góry ustalone kompetencje, sposoby postępowania i egzekwowania swoich praw, czyli pełnią w tych kontaktach przypisane im role prawne. Celami realizowanymi w obrębie tego dyskursu jest nakłonienie/zmuszenie adresata do wykonania określonego działania pod groźbą konkretnych sankcji prawno-administracyjnych. Pole interpretacji w tym dyskursie jest dla przeciętnego obywatela prawie niedostępne, bowiem bez znajomości wykładni prawnej nie ma możliwości zinterpretowania przepisów. Pole interpretacji w tym dyskursie wymaga od odbiorcy wiedzy prawniczej, bez niej może tylko zaufać kompetentnemu interpretatorowi, mającemu kompetencje do interpretacji prawa. Nie wystarczy tu, niestety, doskonała znajomość języka, bowiem nawet interpretacje przepisów prawnych przez lingwistów są podważane przez prawników. Teksty prawne i urzędowe są realizowane w postaci graficznej jako akty prawne: uchwały, ustawy, rozporządzenia itd.' Jako przykłady mogą służyć następujące teksty - pierwszy to fragment aktu prawnego, jakim jest Konstytucja RP (5), a drugi to tekst urzędowy - podanie (6):

\section{(5) Rozdziat II}

\section{WOLNOŚCI, PRAWA I OBOWIAZZKI CZŁOWIEKA I OBYWATELA.} ZASADY OGÓLNE

Art. 30.

Przyrodzona i niezbywalna godność człowieka stanowi źródło wolności i praw człowieka i obywatela. Jest ona nienaruszalna, a jej poszanowanie i ochrona jest obowiązkiem władz publicznych.

\section{Art. 31.}

Wolność człowieka podlega ochronie prawnej.

Każdy jest obowiązany szanować wolności i prawa innych. Nikogo nie wolno zmuszać do czynienia tego, czego prawo mu nie nakazuje.

Ograniczenia w zakresie korzystania z konstytucyjnych wolności i praw moga być ustanawiane tylko w ustawie i tylko wtedy, gdy sa konieczne w demokratycznym państwie dla jego bezpieczeństwa lub porządku publicznego, bądź dla ochrony środowiska, zdrowia i moralności publicznej, albo wolności i praw innych osób. Ograniczenia te nie moga naruszać istoty wolności i praw. [...]

Konstytucja RP

9 Szczegółowy opis dyskursu prawnego/urzędowego przedstawiliśmy w cytowanej książce Wprowadzenie do gramatyki komunikacyjnej. 
(6) Wrocław, 10.10.2000 r.

Adam Węch

ul. Konstytucji 1

56-555 Wrocław

NIP: 777-302-30-01

\author{
Urząd Skarbowy \\ Ul. Rybacka 10 \\ 55-555 Wrocław
}

\title{
Podanie
}

Zwracam się z uprzejmą prośbą o umorzenie mi pozostałej części podatku od darowizny w kwocie 1251 zł. Darowizna, od której pozostała mi jeszcze do zapłacenia kwota 1251 zł, jest położona na Mazurach i jest to stary, zaniedbany domek z działką. Jestem skromnym pracownikiem Urzędu Miejskiego, a moja żona jest kolejarzem. Na utrzymaniu mamy 4 małych dzieci. W chwili obecnej nie mamy środków na zapłatę pozostałej części podatku od darowizny, jaką uczynił mi mój ojciec.

Dziękuję za pozytywne rozpatrzenie mojej prośby. Adam Węch

Nakazy, zakazy, informacje urzędowe itp. mogą mieć też formę graficzną (Fot. 1-2), np.:

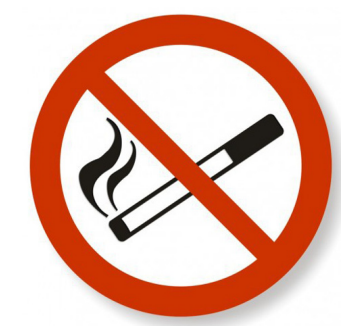

Fot. 1. Zakaz palenia

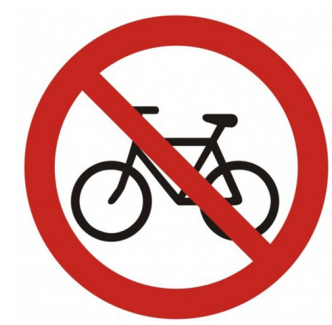

Fot. 2. Zakaz jazdy rowerem

Dyskurs publicystyczny powstał w wyniku rozwinięcia modułu aksjologicznego $\mathrm{w}$ dyskursie potocznym. W tym przypadku nastąpiło poszerzenie ocenianej rzeczywistości z obszaru życia codziennego do problemów życia społecznego. Podstawowym wyróżnikiem tekstów powstających w obrębie dyskursu publicystycznego jest perswazja, czyli wywieranie wpływu na odbiorców. Wpływ ten ma powodować zmiany lub umocnienie ich systemów przekonań i motywować ich zachowanie się w społeczeństwie. Nadawcami (autorami) dyskursu publicystycznego są zazwyczaj dziennikarze i redaktorzy radiowo-telewizyjni, którzy przedstawiając opinie określonych grup społecznych, dążą do tego, by wpłynąć na odbiorców 
i kształtować ich postawy w pożądanym kierunku. Często również autorami tekstów publicystycznych są uczestnicy rozmów, dyskusji i debat, politycy i działacze społeczni wyrażający swą własną opinię, nie będąc profesjonalnymi dziennikarzami. Ostatnio, kiedy wiele osób zrezygnowało z kupowania gazet i posiadania telewizora, coraz częściej teksty w obrębie tego dyskursu tworzą także internauci. Odbiorcą tych tekstów publicystycznych jest całe społeczeństwo, a ściślej mówiąc, przede wszystkim ci, którzy czynnie uczestniczą w komunikacji społecznej, regularnie czytają prasę, świadomie oglądają informacyjne i polityczne programy telewizyjne, regularnie przeglądają i komentują informacje na stronach internetowych, blogach oraz portalach społecznościowych.

Nadawca tekstu w dyskursie publicystycznym stosuje różnorodne środki perswazyjne, odwołujące się zarówno do racjonalnych (rozumowych) argumentów, jak i do irracjonalnych chwytów, wykorzystujących przekonania i przeżywanie emocjonalne odbiorców w stosunku do obiektów perswazji. W tym dyskursie dominuje argumentacja aksjologiczna (7-8), wykorzystująca znane w danej kulturze reguły heurystyczne, podzielane przez pewne grupy społeczne, a odrzucane przez inne ${ }^{10}$. Na przykład:

(7) $(\mathrm{RO})^{11}$ : prezydenta należy szanować

(SK): Andrzej Duda jest prezydentem

(K): Andrzeja Dudę należy szanować

(RO): osoby niepetnosprawne wymagaja poświęcenia rodziny

(SK): Kowalski jest osoba niepetnosprawna

(K): Kowalski wymaga poświęcenia rodziny

Cel ten znajduje potwierdzenie w wyborze odpowiednich środków przekazu, głównie nacechowanych emocjonalnie, opartych na społecznym wymogu solidarności uczuć, ich subiektywnym charakterze, okazjonalnych dowodach, uwzględniających aktualny stan nastrojów społecznych.

Teksty publicystyczne są bardzo zróżnicowane i pojawiają się przede wszystkim w środkach masowego przekazu. Odgrywają ogromną rolę w kształtowaniu opinii publicznej i integracji społecznej, tworzą wizerunki rządzących, partii politycznych i ich przedstawicieli, przedstawiają najważniejsze problemy życia społecznego i gospodarczego. Występują w formie tekstów drukowanych, fonicznych realizacji audycji radiowych i telewizyjnych, dyskusji polityków, dziennikarzy, czasem ekspertów, w tym transmisji debat sejmowych, fotoreportaży, filmów dokumentalnych, memów, reklam itd. Ze względu na tę różnorodność teksty powstające w obrębie

10 A. Awdiejew, Ideologia, postawa a komunikacja, w: Ideologie w słowach i obrazach, red. I. Kamińska-Szmaj, T. Piekot, M. Poprawa, Wydawnictwo Uniwersytetu Wrocławskiego, Wrocław 2008, s. 65-72.

11 (RO) - reguła ogólna; (SK) - sąd kwalifikujący; (K) - konkluzja 
dyskursu publicystycznego wymagają równie różnorodnych kompetencji do interpretacji. Z jednej strony są to kompetencje związane z tematem - czyli wiedza społeczno-polityczna w zakresie, którego dotyczy tekst. A z drugiej strony kompetencje związane z umiejętnością interpretacji różnych kodów przekazu - werbalnego, wizualnego (fotografia, obraz), dźwiękowego (w tym przede wszystkim muzycznego), zwłaszcza kiedy są one ze sobą łączone, tworząc jeden tekst (film, mem, reklama) ${ }^{12}$. Oto kilka przykładów tekstów publicystycznych:

- fragment wywiadu prasowego (9)

(9) Przemysław Szubertowicz: Nie sądzi pani, że nad Polską unoszą się coraz gęstsze opary głupoty? Mimo wolności, gospodarczych przeobrażeń, demokracji. Olga Lipińska: Wie pan, demokracja ma to do siebie, że każdy czuje się w obowiązku, by zaprezentować swoje myśli. Tylko że nie każdy myśli. I dlatego jest, jak jest. Głupota istniała zawsze, ale teraz można powiedzieć, że jest szczególnie medialna. Narodowy i religijny patos zmieszany z niechlujstwem i arogancją władzy. Można się poczuć pewnie w oparciu o motłoch? Można. Cel uświęca środki i jeszcze kilka takich zasad i hejże na Soplicę! A ja chciałabym wiedzieć, dlaczego tylko jeden pan ma patent na ,udoskonalenie" mojej ojczyzny? [...] Dlaczego rząd szasta moimi pieniędzmi? Bez pytania?

- zdjęcia reportażowe/dokumentujące (Fot. 3-5)

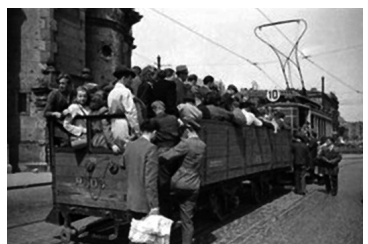

Fot. 3. Tramwaj 1947-1948 ${ }^{13}$

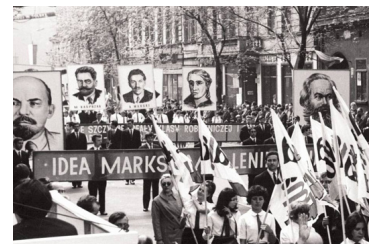

Fot. 4. 1 maja $^{14}$

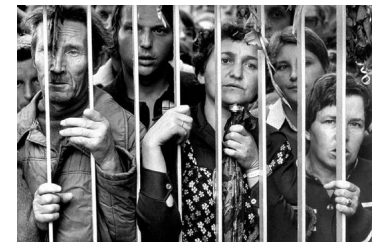

Fot. 5. Sierpień 1980

(c) Bogusław Nieznalski ${ }^{15}$

12 Szczegółowy opis dyskursu publicystycznego przedstawiliśmy w cytowanej książce Wprowadzenie do gramatyki komunikacyjnej.

$13 \mathrm{https}: / /$ www.google.com/search?q=fotografia+dokumentalna+Warszawa+tramwaje\&hl=pl\&tb $\mathrm{m}=$ isch\&source=iu\&ictx=1\&fir=hfeHSLIGcnHDyM\%253A\%252CPNDUbg-s8qcUtM\%252C_\&u sg=_-27ciQ8XKqSJCcx8sQ85gJKGHzUc\%3D\&sa=X\&ved=oahUKEwisxp38ie7aAhUMiCwKHQ UxA9IQ9QEIKTAA\#imgrc=HgEDNmitcJYEDM:\&spf=1525506345433 [dostęp: 5.01.2019].

14 http://www.dzienniklodzki.pl/historia/a/1-maja-w-prl-pierwszomajowe-pochody-paradowaly-ulicami-naszych-miast,9932080/ [dostęp: 5.01.2019].

15 https://adrianwykrota.fotoblogia.pl/279,co-z-ta-fotografia-dokumentalna-rozwoj-polskiego-dokumentu-i-reportazu [dostęp: 5.01.2019]. 
- memy

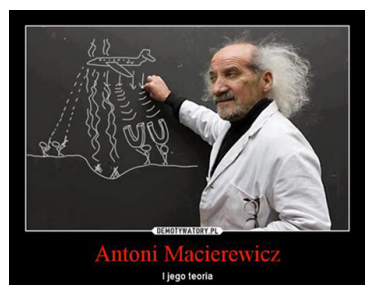

Fot. 6. Mem $1^{16}$

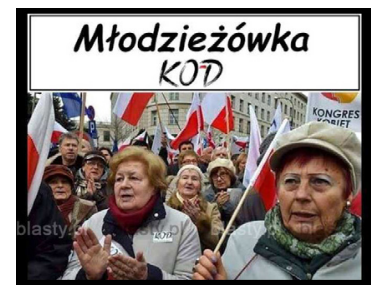

Fot. 7. Mem $2^{17}$

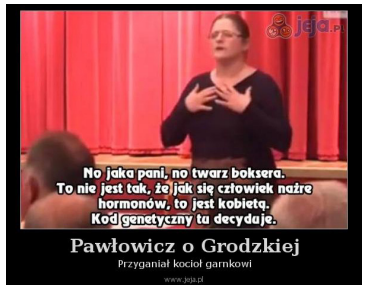

Fot. 8. Mem $3^{18}$

Memy wymagają do zrozumienie dodatkowej wiedzy dyskursywnej o osobach lub sytuacjach w nich ukazywanych. Bez tej wiedzy trudno nam odczytać intencję perswazyjną autorów tych komunikatów. Interpretując mem 1, musimy wiedzieć, czym jest teoria naukowa, że na tablicy rysowany jest schemat katastrofy samolotu w Smoleńsku i musimy znać rolę Antoniego Mecierewicza w głoszeniu jego koncepcji o zamachu (Fot. 6), musimy wiedzieć, dlaczego demonstrujące starsze kobiety nazwano młodzieżówką (Mem 2 - Fot. 7) i musimy wiedzieć, kim są Pawłowicz i Grodzka oraz jakie reprezentują poglądy (Mem 3 - Fot. 8).

- reklama

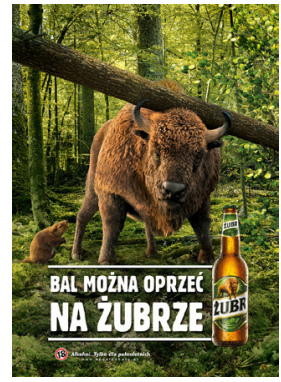

Fot. 9. Reklama piwa ŻUBR ${ }^{19}$

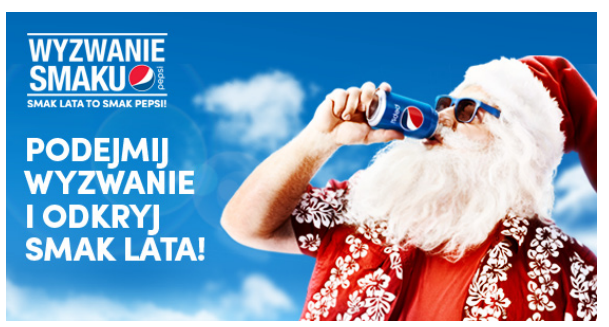

Fot. 10. Reklama napoju PEPS| ${ }^{\mathbf{2 0}}$

16 https://demotywatory.pl/3972302/Antoni-Macierewicz [dostęp: 5.01.2019].

$17 \mathrm{https} / /$ www.google.com/search?q=memy+PiS+m\%C5\%82odzie\%C5\%BC\%C3\%B3wka\&hl=p I\&tbm=isch\&tbo=u\&source=univ\&sa=X\&ved=oahUKEwil1JSk3NDbAhXD3SwKHfJoAScQsA QIJg\&biw=1093\&bih=496\#imgrc=By2py3RREvbJQM: [dostęp: 5.01.2019].

$18 \mathrm{https} / / /$ www.google.com/search?q=Paw\%C5\%82owicz+i+Grodzka+memy\&hl=pl\&tbm=isch\& tbo $=u \&$ source $=u n i v \& s a=X \& v e d=0 a h U K E w j S I Z n V_{3} N D b A h W B G S w K H b g U C U s Q s A Q I J g \& b i w$ $=1093 \&$ bih=496\#imgrc=7Mr1B|gAUoETjM:\&spf=1528895797035 [dostęp: 5.01 .2019 ].

$19 \mathrm{https} / /$ www.google.pl/search?q=reklamy+piwa+\%C5\%BBubr\&hl=pl\&tbm=isch\&tbo=u\&sour ce=univ\&sa=X\&ved =oahUKEwjhlu7V 3 PbQAhUIXiwKHeCKAJAQsAQIJQ\&biw=1188\&bih=55 9\#imgrc=QXdY5ISNMuV--M: [dostęp: 5.01.2019].

20 https://www.google.pl/search?hl=pl\&biw=1092\&bih=635\&tbm=isch\&sa=1\&ei=870wX KTjCsPVwQL484uoDg\&q=reklamy+PEPSI+-+wyzwanie+smaku\&oq=reklamy+PEPSI+- 
Także w przypadku reklam do ich interpretacji niezbędne jest wprowadzenie wiedzy dyskursywnej, najczęściej z dyskursu potocznego, choć same należą do dyskursu publicystycznego, mając cel perswazyjny i agitacyjny. Nawiązanie do dyskursu potocznego wymaga zastosowania $\mathrm{w}$ interpretacji schematów predykatywnych i standardów semantycznych. Reklama piwa Żubr (Fot. 9) wykorzystuje schematy predykatywne OPRZEĆ SIĘ [COŚ1 NA CZYMŚ2] i OPRZEĆ [KTOŚ, COŚ, NA CZYMŚ]. Obraz wskazuje na sens fizyczny: OPRZEĆ SIĘ [coś1: BAL, na czymś2: NA ŻUBRZE], a hasło i fotografia reklamowanego produktu na sens metaforyczny: NA BALU > PIĆ [ktoś: ?, coś: PIWO ŻUBR] \& DOBRZE > NA BALU > BAWIĆ SIĘ [ktoś: ?]. Przywołanie przez odbiorcę tych schematów umożliwia realizację celu perswazyjnego i agitacyjnego:

RO: przy piwie ŻUBR każdy dobrze się bawi

SK: ty chcesz się dobrze bawić (na balu)

K: kup piwo ŻUBR (i zabierz na bal)

Interpretację reklamy popularnego napoju PEPSI (Fot. 10) rozpoczynamy od analizy hasła reklamowego: Podejmij wyzwanie i odkryj smak lata, zauważając nawiązanie do schematu predykatywnego: ODKRYĆ [KTOŚ, COŚ], zdetrywializowanego do postaci: ODKRYĆ [KTOŚ, coś: NOWY lub DOBRY > SMAK]. Następnie rzucają się w oczy standardy semantyczne: BYĆ GORĄCO [LATEM] $\rightarrow$ PIĆ [KTOŚ, COŚ] \& BYĆ ZIMNE [COŚ], co zostało zdetrywializowane w postaci: LATEM > PIĆ [KTOŚ, coś: ZIMNE > NAPOJE] \& MIEĆ [ZIMNE > NAPOJE, SMAK LATA]. Doprowadza to do zauważenia relacji: BYĆ DOBRY [SMAK LATA] i zauważenia metafory: ODKRYĆ [KTOŚ, SMAK LATA]. Przyglądając się dalszym elementom tekstu umieszczonego na reklamie odbiorca czyta: SMAK LATA TO SMAK PEPSI (napisane wprost), co prowadzi do konkluzji: ODKRYĆ [KTOŚ, SMAK LATA] to ODKRYĆ [KTOŚ, SMAK PEPSI]. Wreszcie zinterpretować trzeba jeszcze powtórzone dwukrotnie „wyzwanie”, które wskazuje na schemat predykatywny: WYZWAĆ [KTOŚ1, KOGOŚ2, na coś: NA POJEDYNEK] \& PODJĄĆ [KTOŚ2, coś: WYZWANIE]. Autorzy reklamy zastosowali tu chwyt personifikacji smaku PEPSI do człowieka, co umożliwiło zdetrywializowanie tego schematu do postaci: WYZWAĆ [ktoś1: SMAK (PEPSI), KOGOŚ2, do czegoś1: PIĆ (KTOŚ2, coś2: PEPSI)] \& PODJĄĆ [KTOŚ2, coś3: WYZWANIE]. Obraz wnosi tu nowe treści, bowiem postać św. Mikołaja pijącego PEPSI latem jest propozycją picia tego napoju przez cały rok.

Najsłabiej zbadany w teorii komunikacji pozostaje dyskurs artystyczny, będący rozwinięciem modułu ludycznego $\mathrm{w}$ dyskursie potocznym. Jego odziedziczonym celem komunikacyjnym jest przeżycie estetyczne, zmienił się tylko i ogromnie poszerzył repertuar środków, dających takie przeżycie. Pojęcie przeżycia estetyczne-

-+wyzwanie+smaku\&gs_l=img.3...0.0..54886...0.0..0.0.0..............gws-wiz-img.ISRSZidebIA\#i mgrc=UcSYS4BElkZqjM: [dostęp: 5.01.2019]. 
go ma charakter bardzo niejasny i złożony. Można jednak wyróżnić w nim cztery podstawowe komponenty. Pierwszym z nich jest specyficzne dla każdego prądu w sztuce obrazowanie świata. Świat przedstawiony w tych tekstach jest zazwyczaj fikcyjny, wymyślony przez autora. Nie ma to istotnego znaczenia, ponieważ podstawowym celem nie jest tu informowanie o rzeczywistości, ale aktywne „uczestnictwo" odbiorcy w wymyślonym świecie, jego przeżywanie, co byłoby niemożliwe bez zwiększonej obrazowości i wyrazistości. Takie uczestnictwo ma oczywiście charakter ludyczny. Zdolność do takiego uczestnictwa wynika z możliwości interpretacyjnych i wyobrażeniowych odbiorcy. Wymaga treningu i wrażliwości, nie dla wszystkich dostępnej. Przykładowe teksty werbalne (10) i wizualne (Fot. 11-13):

(10) Nie wychylaj się, spójrz: plac - z rąk mi wypadł, potoczyło się, oddaliło śródmieście, a w górę - gdy nas rozkosz dwoi Niesie podsadzony pięcioma piętrami pokoik!

Poza rozwarte okno, ścian nabitych - wypał, z twego ciała wycałuj mnie w śmigłą przestrzeń! Niebo obrywa się błyskawicznie w dół, w wichurę, i drga burzą nagie powietrze.

Na niebie, z burzy, którą piorun błyskawicą spruł, rozrabiające tęczę śmigło!

Julian Przyboś Burza 


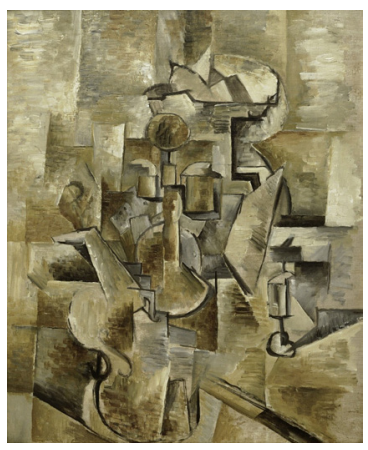

Fot. 11. Violín y candelabro George Braque ${ }^{21}$

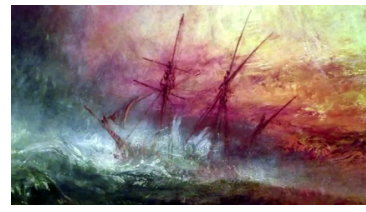

Fot. 12. Statek handlarzy niewolników William Turner ${ }^{22}$

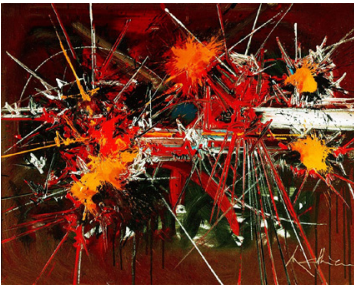

Fot. 13. Abstarkcjonizm ekspresyjny George Mathieu ${ }^{23}$

Drugim komponentem przeżycia estetycznego jest jego subiektywne przeżywanie. Wiąże się ono głównie z przeżywaniem wzruszeń o różnym podłożu, na przykład miłości, czułości, zachwytu itd. W literaturze przykładami są opisy uczuć i opisy przyrody (11-13), w kodzie wizualnym przedstawianie wzruszających scen i również obrazów natury (Fot. 14-18). Oto kilka takich przykładów:

(11) Ty przychodzisz jak noc majowa, biała noc, noc uśpiona w jaśminie, i jaśminem pachną twoje słowa, i księżycem sen srebrny płynie. [...]

Władysław Broniewski, Poezja

(12) Bóg stworzył świat

bo chciał pogłaskać kota

i oprzeć się wieczorem

o szarozłoty brzozy pień

21 https://pl.pinterest.com/pin/196188127490927310/ [dostęp: 5.01.2019].

22 https://www.google.pl/search?q=romantyzm+malarstwo\&hl=pl\&dcr=1\&tbm=isch\&source=iu

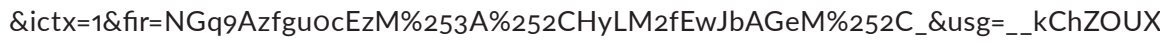
7MpCjIPYM1UsWU6KqZok\%3D\&sa=X\&ved=oahUKEwjyocmW_v_ZAhWrxaYKHW2uBmU Q9QEIUjAG\#imgrc=upZpsucL9sPD7M:\&spf=1521723638092 [dostęp: 5.01 .2019 ].

23 https://www.google.pl/search?q=abstrakcjonizm\&sa $=N \& h l=p l \& d c r=1 \& b i w=1093 \& b$ $\mathrm{ih}=496 \& \mathrm{tbm}=\mathrm{isch} \&$ source $=$ iu \&ict $x=1 \& \mathrm{fir}=\mathrm{LzRh} 4 \mathrm{CXzE}$ ZZ $58 \mathrm{M} \% 253 \mathrm{~A} \% 252 \mathrm{COBy}-\mathrm{rH}-$ 3ZkCeRM\%252C_\&usg=_KHfybWZVpAjjYHa_5C7ivmrzcmQ\%3D\&ved=oahUKEwiTxtGyn YDaAhWiBZoKHeYmDYc4ChD1AQgoMAA\#imgrc=PgdYtJHF6ZAf5M:\&spf=1521731988468 [dostęp: 5.01.2019]. 
Bóg stworzył świat

bo chciał ciebie przytulić

Joanna Ślósarska, Genesis z czułości

(13) A niebo poczęło się zaciągać coraz mroczniej; chmury wypełzały ze wszystkich jam, podnosiły potworne łby, przeciągały zgniecione kadłuby, rozwichrzały sine grzywy, zielonawymi kłami błyskały i szły całym stadem - groźną, ponurą i milczącą ciżbą waliły się na niebo;

Władysław Reymont, Chłopi

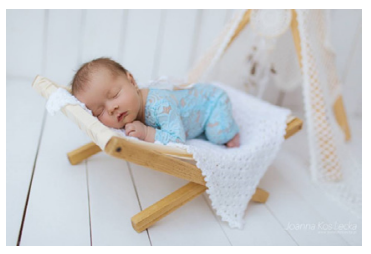

Fot. 14. Autor Joanna Kostecka

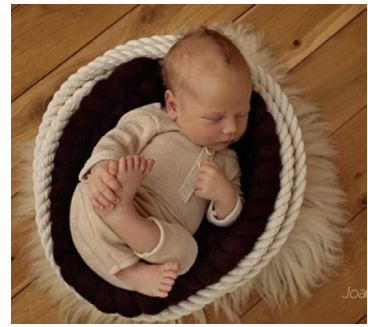

Fot. 15. Autor Joanna Kostecka

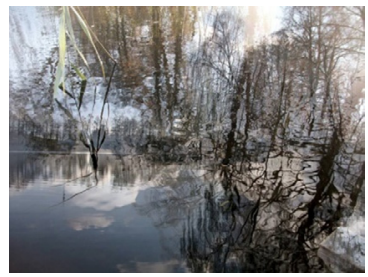

Fot. 16.

Autor Bronisław Czerkas ${ }^{\mathbf{2 4}}$

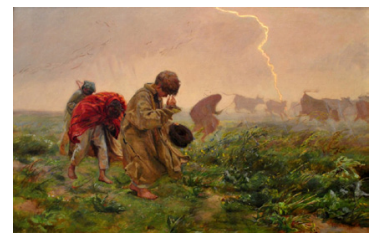

Fot. 17. Przed burzą ${ }^{25}$ Józef Chełmoński

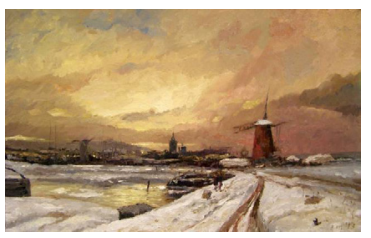

Fot. 18. Zima ${ }^{26}$

Piotr Mastalerz

24 Fotografia w posiadaniu autorki.

25 https://www.google.com/search?hl=pl\&q=przed+burz\%C $4 \% 85+j \% C_{3} \% B 3 z e f+c h e \% C_{5} \% 82 m$ ०\%C5\%84ski\&tbm=isch\&source=iu\&ictx=1\&tbs=simg:CAESvgIJ3S6li5P1wdsasgILEKjU2AQa BAgVCAIMCxCwjKcIGmIKYAgDEiilFaQVxgv4CogLphXVCqcVwwvXFdc-tzq5Org6IDjYPrQ 6tjrLK_10tGjCoQfJPIHfFpKV4apr7pvSU4BLguZMmkQXfJPVAF8Ctcg1tYQB4he3f3u3ZwSB GTokgBAwLEl6u_1ggaCgolCAESBMegY_1kMCxCd7cEJGpoBChoKCHBhaW50aW5n2qWl9gMKCggvbS8wNXFkaAodCgpydXJhbCBhcmVh2qWlggMLCgkvbS8wMWYodGQKIwoQd2 FoZXJjb2xvciBwYWludNqliPYDCwoJL2OvMDE4a3RwChgKBWdyYXNz2qWl9gMLCgkvbS8wOHQ5Y18KIQoOd29ya2luZyBhbmltYWzapYj2AwsKCS9tLzA3X2dtbAw\&fir=17dd8UXFK H7m_M\%253A\%252C404-WDusa3-MxM\%252C_\&usg=Al4_-kRqgx5ZmK6158kIBwHmNFO RZ5AQxg\&sa=X\&ved=2ahUKEwjm1_mfxNffAhUBKIAKHXuYDiQQ9QEwAnoECAYQBA\#img rc=17dd8UXFKH7m_M: [dostęp: 5.01.2019].

26 https://www.touchofart.eu/Piotr-Mastalerz/pmas12-Zima/ [dostęp: 5.01.2019]. 
Trzecim komponentem jest zdolność refleksji, inaczej mówiąc - umiejętność przeżywania mądrości. Zawiera ono zdolność widzenia paradoksów naszego istnienia, umiejętność postrzegania tych samych zjawisk z różnych perspektyw, wyjścia poza stereotypy i zobaczenia rzeczy w niepowtarzalnym, nowym świetle. Przykładem jest tu literatura (14) i sztuka zmuszająca do refleksji:

(14) Ty! co jesteś Miłości-profilem, Któremu na imię Dopełnienie; To - co w Sztuce mianują Stylem, Iż przenika pieśń, kształci kamienie...

O! Ty - co się w Dziejach zowiesz Erą, Gdzie zaś ani historii zenit jest, Zwiesz się razem: Duchem i Literą, I „Consummatum est”...

O! Ty - Doskonałe-wypełnienie, Jakikolwiek jest Twój - i gdzie?... znak...

Czy w Fidiasu? Dawidzie? czy w Szopenie?

Czy w Eschylesowej scenie?...

Zawsze - zemści się na tobie: BRAK!...

- Piętnem globu tego - niedostatek:

Dopełnienie?... go boli!...

On - rozpoczynać woli

I woli wyrzucać wciąż przed się - zadatek!

- Kłos?... gdy dojrzał jak złoty kometa,

Ledwo że go wiew ruszy,

Dészcz pszenicznych ziarn prószy,

Sama go doskonałość rozmieta...

Cyprian Kamil Norwid, Fortepian Szopena 


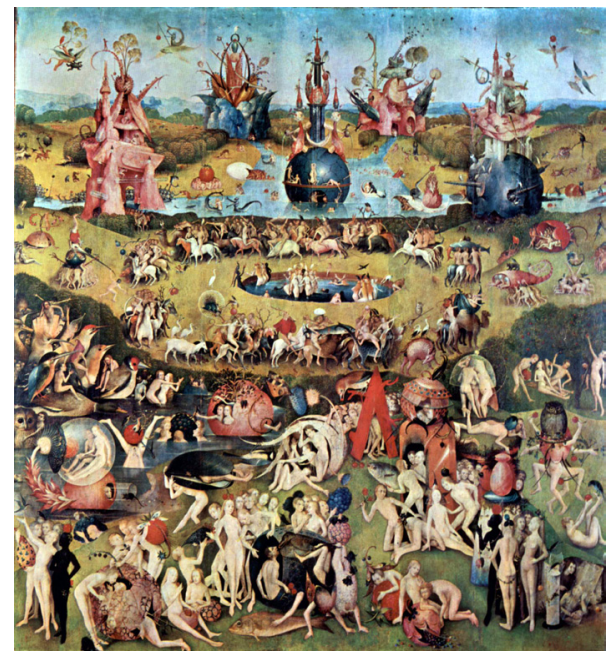

Fot. 19. Ogród rozkoszy ziemskich ${ }^{27}$ Hieronim Bosch

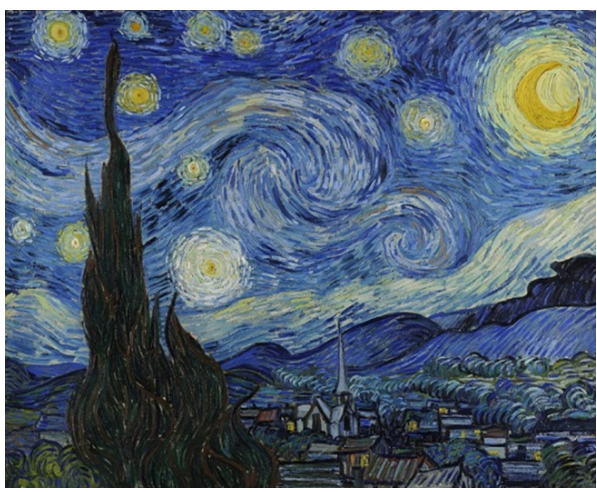

Fot 20. $\mathrm{Noc}^{28}$

Vincent van Gogh

Niesystemowe ujęcie świata i myślenie paradoksalne łączą się bezpośrednio z przeżywaniem komizmu, który jest specyficzną realizacją tego typu myślenia i posiada wartość estetyczną. Przeżywania mądrości nie można porównywać z systematycznym poznaniem naukowym, gdyż w istocie ma ono charakter rozrywkowy. Przykładami są opowiadane dowcipy, anegdoty czy powiedzonka (15-17) oraz obrazy satyryczne (Fot. 21-22), rzadziej obrazy (Fot. 23):

(15) Są dwa ważne powody,

Dla których Polska mi zbrzydła:

Za dużo świeconej wody

Za mało zwykłego mydła.

Jerzy Paczkowski ${ }^{29}$

(16) - Kaziu, gdzie ty - pracujesz?

- Nigdzie.

- A co robisz?

- Nic.

27 https://pl.wikipedia.org/wiki/Ogr\%C3\%B3d_rozkoszy_ziemskich\#/media/File:Hieronymus_ Bosch_023.jpg [dostęp: 5.01.2019].

28 https://pl.wikipedia.org/wiki/Vincent_van_Gogh\#/media/File:Van_Gogh_-_Starry_Night_-_ Google_Art_Project.jpg [dostęp: 5.01.2019].

29 http://naszemiasto.pl/artykul/za-malo-zwyklego-mydla,4527730,art,t,id,tm.html [dostęp: 5.01.2019]. 
- To wspaniałe zajęcie!

- Ale duża konkurencja.

Alosza Awdiejew, Opowiem ci dowcip

(17) Stoi Nowy Ruski nad rzeką i łowi ryby. Wędkę ma ze złota a kołowrotek z platyny. Nagle złapał złotą rybkę. Ale jako ekolog wypuścił ją z powrotem. A rybka wróciła i mówi:

- Jestem złota rybka. Może jakieś życzenie, proszę pana?

- Dobrze - mówi Nowy Ruski - Mów życzenie i spływaj, bo nie mam czasu.

Alosza Awdiejew, Opowiem ci dowcip

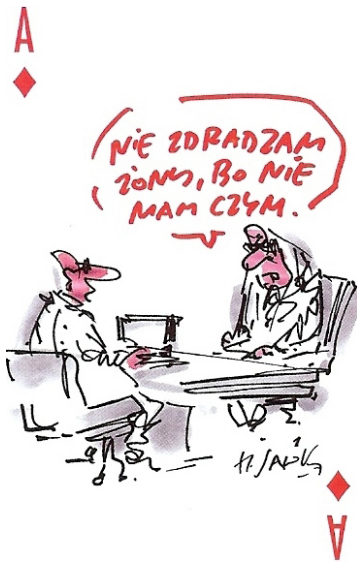

Fot. 21. Henryk Sawka ${ }^{30}$

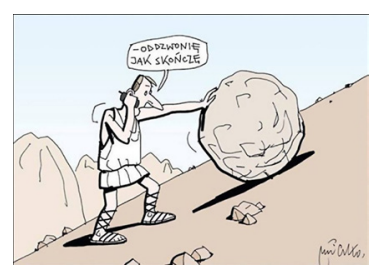

Fot. 22. Andrzej Mleczko ${ }^{31}$

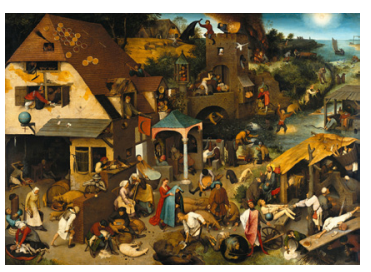

Fot. 23. The Dutch Proverbs ${ }^{32}$ Pieter Brueghel Starszy

Czwartym i najbardziej zauważalnym czynnikiem powodującym przeżycie estetyczne jest formalna organizacja tekstu artystycznego. Opis tej organizacji można znaleźć w licznych opracowaniach i analizach różnych dzieł sztuki: literatury, malarstwa, rzeźby, architektury, filmu, muzyki itd. Jak widać, teksty powsta-

30 https://www.google.com/search?hl=pl\&biw=1092\&bih=635\&tbm=isch\&sa=1\&ei=mbwwXJXn Cc_srgSOs6HACw\&q=henryk+sawka+rysunki+satyryczne+nie+zdradzam\&oq=henryk+sawka+ rysunki+satyryczne+nie+zdradzam\&gs_l=img.3...65126.67329..67571...0.0..0.118.903.12j1..........1.. gws-wiz-img........oi30.Rrh5ivon490\#imgrc=4C2uB195U5FDwM: [dostęp: 5.01.2019].

$31 \mathrm{https}: / /$ www.google.com/search?q=mleczko+rysunki+i+aforyzmy\&hl=pl\&tbm=isch\&tbo=u\&s ource=univ\&sa=X\&ved=oahUKEwjU5pbgIrfbAhUBqCwKHf4CD6QQsAQIJg\&biw=1093\&bih =496\#imgrc=PCIEO5dT19l5kM:\&spf=1528018379690 [dostęp: 5.01 .2019 ].

32 https://pl.wikipedia.org/wiki/Pieter_Bruegel_(starszy)\#/media/File:Pieter_Brueghel_the_Elder_-_The_Dutch_Proverbs_-_Google_Art_Project.jpg [dostęp: 5.01.2019]. 
jące w obrębie dyskursu artystycznego cechuje największa ze wszystkich dyskursów różnorodność i bogactwo form. Pola interpretacji są w tym przypadku różne, zależne od rodzaju tekstu ${ }^{33}$. Niżej umieszczam przykłady formalnej organizacji tekstów werbalnego - wiersz (18) i wizualnych - obraz (Fot. 24), rzeźba (Fot. 25) i architektura (Fot. 26), których forma wywołuje przeżycia estetyczne.

(18) Wtedy gdym biegło za aniołami

a ziemia jak zatrwożona matka

plątała moje korzenie

i zasypywała żwirem

Wtedy

gdy błękitniałom

kwitnąc i szumiąc

w rozpalone usta słońca

i nie pamiętałom o podziemnych strumieniach

nie pamiętałom pić

i gdym umierało biegnąc

w tiulach powietrza

coraz wyżej

śniłom buciki na korzeniach

z purpurowymi wstążkami i dzwoneczkami

śniłom swoje delikatne stopy

na miękkich chmurach

i poustawiane obok buciki

wszyscy aniołowie mówili mi

żem oszalało

ale ja śmiałom się z ich lęku

i wyszedł do mnie Bóg

który był szewcem

i mnie ubrał

Joanna Ślósarska, Monolog leśnego drzewa ${ }^{34}$

33 Szczegółowy opis dyskursu artystycznego przedstawiliśmy w cytowanej książce Wprowadzenie do gramatyki komunikacyjnej.

34 Wiersz dedykowany przez autorkę prof. Annie Krupskiej-Perek. 


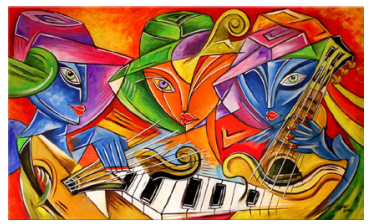

Fot. 24. Musical

Thomas Lange ${ }^{35}$

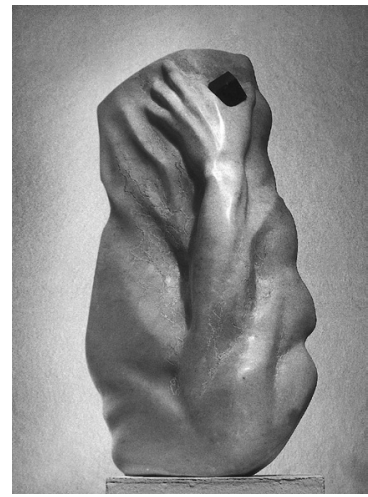

Fot. 25. Staccato

Zbigniew Władyka ${ }^{36}$

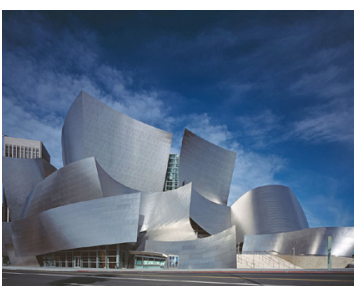

Fot. 26. Sala koncertowa Walt Disney projekt Frank Gehry ${ }^{37}$

Jak widać, każdy dyskurs wprowadza odmienne reguły interpretacji, których uczestnik musi się nauczyć. Dyskursy rozwijają się, istnieją we własnych polach interpretacyjnych. Uczestnictwo $\mathrm{w}$ dyskursie równocześnie rozszerza i usprawnia jego pole interpretacyjne. Kiedy człowiek nie uczestniczy w danym dyskursie, to $\mathrm{z}$ tego dyskursu wypada. Pamiętać trzeba, że ludzie mają różny stopień gotowości uczestniczenia w poszczególnych dyskursach.

\section{Bibliografia}

Awdiejew A., Gramatyka interakcji werbalnej, Wydawnictwo Uniwersytetu Jagiellońskiego, Kraków 2004.

Awdiejew A., Ideologia, postawa a komunikacja, w: Ideologie w stowach i obrazach, red. I. Kamińska-Szmaj, T. Piekot, M. Poprawa, Wydawnictwo Uniwersytetu Wrocławskiego, Wrocław 2008, s. 65-72.

Awdiejew A., Logiki dyskursów [w druku].

35 https://www.google.pl/search?q=Kubizm\&sa=N\&hl=pl\&dcr=1\&tbm=isch\&source=iu\&ictx=1\& fir=56vp-sGWU_OdNM\%253A\%252Ci_Xn5npSAp4V3M\%252C_\&usg=__mlHKloRB-RQxGCj IM6rT4dHIv50\%3D\&ved=oahUKEwiS8d-imYDaAhXkApoKHdjMC5k4ChD1AQgoMAA\&biw

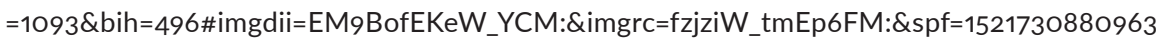
[dostęp: 5.01.2019].

36 Fotografia w posiadaniu autorki.

37 https://internityhome.pl/odkrywaj/trendy/style-architektury-wspolczesnej-przewodnik/ [dostęp: 5.01.2019]. 
Awdiejew A., Habrajska G., Wprowadzenie do gramatyki komunikacyjnej, t. 2, Wydawnictwo Leksem, Łask 2006.

Malinowski B., Ogrody koralowe i ich magia, w: tenże, Dzieła, t. 5, PWN, Warszawa 1987, s. 322-341.

\section{Netografia}

http://naszemiasto.pl/artykul/za-malo-zwyklego-mydla,4527730,art,t,id,tm.html [dostęp: 5.01.2019].

http://www.dzienniklodzki.pl/historia/a/1-maja-w-prl-pierwszomajowe-pochody-paradowaly-ulicami-naszych-miast,9932080/ [dostęp: 5.01.2019]. https://adrianwykrota.fotoblogia.pl/279,co-z-ta-fotografia-dokumentalna-rozwoj-

-polskiego-dokumentu-i-reportazu [dostęp: 5.01.2019]. https://demotywatory.pl/3972302/Antoni-Macierewicz [dostęp: 5.01.2019]. https://internityhome.pl/odkrywaj/trendy/style-architektury-wspolczesnej-przewodnik/ [dostęp: 5.01.2019].

https://pl.pinterest.com/pin/196188127490927310/ [dostęp: 5.01.2019]. https://pl.wikipedia.org/wiki/Ogr\%C3\%B3d_rozkoszy_ziemskich\#/media/

File:Hieronymus_Bosch_023.jpg [dostęp: 5.01.2019]. https://pl.wikipedia.org/wiki/Pieter_Bruegel_(starszy)\#/media/File:Pieter_ Brueghel_the_Elder_-_The_Dutch_Proverbs_-_Google_Art_Project.jpg [dostęp: 5.01.2019].

https://pl.wikipedia.org/wiki/Vincent_van_Gogh\#/media/File:Van_Gogh_-_Starry_Night_-_Google_Art_Project.jpg [dostęp: 5.01.2019].

https://www.google.com/search?hl=pl\&biw=1092\&bih=635\&tbm=isch\&sa=1\&ei=m bwwXJXnCc_srgSOs6HACw\&q=henryk+sawka+rysunki+satyryczne+nie+zdr adzam\&oq=henryk+sawka+rysunki+satyryczne+nie+zdradzam\&gs_l=img.3...6 5126.67329..67571...0.0..0.118.903.12j1..........1..gws-wiz-img.......0i30.Rrh5ivon49 o\#imgrc=4C2uB195U5FDwM: [dostęp: 5.01.2019].

https://www.google.com/search?hl=pl\&q=przed+burz\%C4\%85+j\%C3\%B3zef+ che\%C5\% 82mo\%C5\%84ski\&tbm=isch\&source=iu\&ictx=1\&tbs=simg:CAE SvgIJ3S6Ii5P1wdsasgILEKjU2AQaBAgVCAIMCxCwjKcIGmIKYAgDEiilFaQVxgv4CogLphXVCqcVwwvXFdc-tzq5Org6lDjYPrQ6tjrLK_10tGjCoQfJPl HfFpKV4apr7pvSU4BLguZMmkQXfJPVAF8Ctcg1tYQB4he3f3u3ZwSBGTokg BAwLEI6u_1ggaCgoICAESBMe9Y_1kMCxCd7cEJGp0BChoKCHBhaW50aW5n2qWI9gMKCggvbS8wNXFkaAodCgpydXJhbCBhcmVh2qWI9gMLCgkv bS8wMWY0dGQKIwoQd2F0ZXJjb2xvciBwYWludNqliPYDCwoJL20vMDE4a3RwChgKBWdyYXNz2qWI9gMLCgkvbS8wOHQ5Y18KIQoOd29ya2luZyBhbmltYWzapYj2AwsKCS9tLzA3X2dtbAw\&fir=17dd8UXFKH7m_M\%253A 
\%252C404-WDusa3-MxM\%252C_\&usg=AI4_-kRqgx5ZmK6I58kIBwHmNFO RZ5AQxg\&sa=X\&ved=2ahUKEwjm1_mfxNffAhUBKlAKHXuYDiQQ9QEwA noECAYQBA\#imgrc=17dd8UXFKH7m_M: [dostęp: 5.01.2019].

https://www.google.com/search?q=fotografia+dokumentalna+Warszawa+tramwaje \&hl $=$ pl\&tbm $=$ isch\&source $=\mathrm{iu} \& \mathrm{ict}=1 \& \mathrm{fir}=\mathrm{hfeHSLIGcnHDyM} \% 253 \mathrm{~A} \% 252 \mathrm{CP}$ NDUbg-s8qcUtM\%252C_\&usg=__27ciQ8XKqSJCcx8sQ85gJKGHzUc\%3D\&sa $=X \& v e d=0$ ahU KEwisxp38ie7aAhUMiCwKHQUxA9IQ9QEIKTAA\#imgrc=Hg EDNmitcJYEDM:\&spf=1525506345433 [dostęp: 5.01.2019].

https://www.google.com/search?q=memy+PiS +m\%C5\% 82 od zie $\%$ C5\%BC $\% \mathrm{C} 3 \% \mathrm{~B} 3 \mathrm{wka} \& \mathrm{hl}=\mathrm{pl} \& \mathrm{tbm}=\mathrm{isch} \& \mathrm{tbo}=\mathrm{u} \&$ source $=$ univ \&sa $=\mathrm{X} \& v e d=0 \mathrm{ah}$ UKEwillJSk3NDbAhXD3SwKHfJ0AScQsAQIJg\&biw=1093\&bih=496\#imgrc=By2py3RREvbJQM: [dostęp: 5.01.2019].

https://www.google.com/search?q=mleczko+rysunki+i+aforyzmy\&hl=p $1 \& \mathrm{tbm}=\mathrm{isch} \& \mathrm{tbo}=\mathrm{u} \&$ source $=\mathrm{univ} \& \mathrm{sa}=\mathrm{X} \& \mathrm{ved}=0 \mathrm{ahU} \mathrm{KEwjU5 \textrm {pbglrf }}$ bAhUBqCwKHf4CD6QQsAQIJg\&biw $=1093 \&$ bih $=496 \#$ imgrc $=$ PCIE O5dT1915kM:\&spf=1528018379690 [dostęp: 5.01.2019].

https://www.google.com/search?q=Paw\%C5\%82owicz+i+Grodzka+memy\&hl=pl $\& \mathrm{tbm}=\mathrm{isch} \& \mathrm{tbo}=\mathrm{u} \&$ source $=$ univ\&sa $=\mathrm{X} \& v e d=0$ ahUKEwjSlZnV3NDbAhWB GSwKHbgUCUsQsAQIJg\&biw=1093\&bih=496\#imgrc=7Mr1BlgAU0ETjM:\&s $\mathrm{pf}=1528895797035$ [dostęp: 5.01.2019].

https://www.google.pl/search?hl=pl\&biw=1092\&bih=635\&tbm=isch\&sa=1\&ei=87 0wXKTjCsPVwQL484uoDg\&q=reklamy+PEPSI+-+wyzwanie+smaku\&oq=re klamy+PEPSI+-+wyzwanie+smaku\&gs_l=img.3...0.0..54886...0.0..0.0.0............. gws-wiz-img.ISRSZidebIA\#imgrc=UcSYS4BEIkZqjM: [dostęp: 5.01.2019].

https://www.google.pl/search?q=abstrakcjonizm\&sa=N\&hl=pl\&dcr=1\&biw=1093\& $\mathrm{bih}=496 \& \mathrm{tbm}=\mathrm{isch} \&$ source $=$ iu\&ictx $=1 \&$ fir $=\mathrm{LzRh} 4 \mathrm{CXzE9Z58M} \% 253 \mathrm{~A} \% 252 \mathrm{C}$ OBy-rH-3ZkCeRM\%252C_\&usg=__KHfybWZVpAjjYHa_5C7ivmrzcmQ\%3D \&ved=0ahUKEwiTxtGynYDaAhWiBZoKHeYmDYc4ChD1AQgoMAA\#imgrc $=$ PgdYtJHF6ZAf5M:\&spf=1521731988468 [dostęp: 5.01.2019].

https://www.google.pl/search?q=Kubizm\&sa=N\&hl=pl\&dcr $=1 \& \mathrm{tbm}=$ isch \& source $=i u \& i c t x=1 \&$ fir $=56 \mathrm{vp}-\mathrm{sGWU}$ _OdNM\%253 A $\% 252 \mathrm{Ci}_{-}$ Xn5npSAp4V3M\%252C_\&usg=__mlHKIoRB-RQxGCjlM6rT4dHIv5o \%3D\&ved=0ahUKEwiS8d-imYDaAhXkApoKHdjMC5k4ChD1AQgoM AA\&biw $=1093 \&$ bih=496\#imgdii=EM9BofEKeW_YCM:\&imgrc=fzjziW tmEp6FM:\&spf=1521730880963 [dostęp: 5.01.2019].

https://www.google.pl/search?q=reklamy+piwa $+\%$ C5\%BBubr\&hl=pl\&tbm=isch\&tb $\mathrm{o}=\mathrm{u} \&$ source $=$ univ\&sa $=$ X\&ved $=0$ ahUKEwjhlu7V3PbQAhUIXiwKHeCKAJAQs AQIJQ\&biw $=1188 \& b i h=559 \#$ imgrc $=$ QXdY51SNMuV--M: [dostęp: 5.01.2019]. https://www.google.pl/search?q=romantyzm+malarstwo\&hl=pl\&dcr=1\&tbm=isch \&source=iu\&ictx=1\&fir=NGq9Azfgu0cEzM\%253A\%252CHyLM2fEwJbAGeM 
\%252C_\&usg=__kChZOUX7MpCjIPYM1UsWU6KqZ0k\%3D\&sa=X\&ved=0a hUKEwjyocmW_v_ZAhWrxaYKHW2uBmUQ9QEIUjAG\#imgrc=upZpsucL9s PD7M:\&spf=1521723638092 [dostęp: 5.01.2019]. https://www.touchofart.eu/Piotr-Mastalerz/pmas12-Zima/ [dostęp: 5.01.2019].

Grażyna Habrajska

\section{Interpretacja tekstów w różnych dyskursach}

Streszczenie

W ujęciu komunikatywistycznym dyskurs to obszar sensów powstałych wskutek interpretacji tekstów, które to sensy pozostają w naszej pamięci i są aktywowane $\mathrm{w}$ miarę potrzeb komunikacyjnych. Sensy tworzące dany dyskurs stanowią swoistą bazę odniesienia - własną logikę. Zatem musimy się nauczyć, jak uczestniczyć w poszczególnych dyskursach. Uwzględniając ogólny cel komunikacyjny i swoistą bazę odniesienia sensu, wyróżniliśmy dyskursy: potoczny, naukowy, urzędowy, publicystyczny i artystyczny, w obrębie których można wyróżniać tematycznie węższe subdyskursy. Teksty tworzone w obrębie poszczególnych dyskursów i subdyskursów mogą mieć formę zarówno werbalną, jak i wizualną. Każdy dyskurs wprowadza odmienne reguły interpretacji, których uczestnik musi się nauczyć. Dyskursy rozwijają się i istnieją we własnych polach interpretacyjnych. Uczestnictwo w dyskursie równocześnie rozszerza i usprawnia jego pole interpretacyjne. Kiedy człowiek nie uczestniczy w danym dyskursie, to z tego dyskursu wypada. Pamiętać trzeba, że ludzie mają różny stopień gotowości uczestniczenia w poszczególnych dyskursach.

Słowa kluczowe: dyskurs, pole interpretacyjne, interpretacja tekstu.

\section{Interpreting Works by Different Discourses}

\section{Summary}

In terms of communicativism, a discourse is a space of meanings created by interpreting the work - its points remaining in our memory and being evoked only to the degree demanded by our communicational needs. Meanings forming an exemplary discourse constitute a reference base, therefore a specific logic. One must learn how 
to participate in individual discourses. Considering the general communicational goal and a specific reference base of meaning we can distinguish colloquial, scientific, official, journalistic and artistic discourse. Each of these can contain a specific sub-discourse. Works created within individual discourse or sub-discourse can take both - verbal and visual form and introduce a different set of rules of interpretation, which must be learnt by the person participating in it. Discourses develop and exist in their own interpretational field - widened and improved by its participants. People who do not constantly take part in given discourse fall out of line with its convention. However, we ought to remember that people have different degrees of willingness to participate in each discourse.

Keywords: discourse, work, interpretation, communicativism, participation.

Grażyna Habrajska - prof. dr hab.; od kilkunastu lat współtworzy z A. Awdiejewem teorię nauki o komunikowaniu, publikując znaczące prace w tej tematyce. Zakres zainteresowań naukowych: teoria i praktyka komunikacji (komunikologia) w zakresie komunikacji werbalnej i wizualnej, gramatyki komunikacyjnej, analizy dyskursu, perswazji i manipulacji, aksjologia w komunikacji itd. Wraz z A. Awdiejewem opublikowała Wprowadzenie do gramatyki komunikacyjnej (t. 1 - 2004, t. 2 - 2006) oraz Komponowanie sensu w procesie odbioru komunikatów (2010). Jest autorką monografii: Komunikacyjna analiza i interpretacja tekstu (2004), Wybrane zagadnienia wprowadzające do nauki o komunikowaniu (2012) oraz ponad stu artykułów naukowych. Jest redaktorem licznych zbiorowych monografii naukowych; od 2007 roku redaguje cykl wydawanych corocznie monografii Rozmowy o komunikacji. 